\title{
Synergy in mixed Nothofagus spp. plantations: the effect of deciduous/evergreen neighbourhood on tree growth in the Chilean Andes
}

\author{
Patricio Ojeda-González ${ }^{1, *}$, Pablo J. Donoso ${ }^{1,3}$ and Alfredo Erlwein ${ }^{2,3}$ \\ ${ }^{1}$ Universidad Austral de Chile, Facultad de Ciencias Forestales y Recursos Naturales, Instituto de Bosques y Sociedad, Isla Teja s/n, Valdivia, Chile. \\ ${ }^{2}$ Universidad Austral de Chile, Instituto de Ingeniería Agraria y Suelos, Valdivia, Chile. \\ ${ }^{3}$ Núcleo Transdisciplinario en Estrategias Socio-Ecológicas para la Sostenibilidad de los Bosques Australes (TESES). Universidad Austral de Chile.
}

*Corresponding author: p.f.ojeda.gonzalez@gmail.com

(Received for publication 24 March 2020; accepted in revised form 3 November 2020)

\begin{abstract}
Background: The genus Nothofagus is a key component of the Valdivian temperate rainforests of South America, and several of its species have shown promising growth in plantations. Plantations with these species are an opportunity to diversify the Chilean forest sector, ideally through mixed-species arrangements, but the existing literature in this regard is scarce. This work aimed to evaluate individual tree growth for three Nothofagus species in a mixed plantation, considering two types of neighbourhoods.

Methods: In a mid-elevation site in the foothills of the Andes ranges we evaluated growth of Nothofagus alpina (Poepp. \& Endl.) Oerst, Nothofagus dombeyi (Mirb.) Oerst and Nothofagus obliqua (Mirb.) Oerst according to their neighbourhood, comprised of evergreen or deciduous tree species. We conducted stem analyses for 30 trees (10 per species, one-half with each type of neighbourhood; 370 cross-sections in total) and compared growth in diameter (d), height (h), and volume (v) for each of the 30 trees with nine nonlinear mixed-effects models.

Results: Nothofagus alpina showed significantly greater cumulative growth in all variables when growing in an evergreen neighbourhood (EN) compared with a deciduous neigbourhood (DN): average diameter ( \pm 1SD) of $15.3 \pm 1.4$ vs. $10.8 \pm$ $2.0 \mathrm{~cm}$; average height $( \pm 1 \mathrm{SD})$ of $15.5 \pm 1.8$ vs. $13.2 \pm 1.0 \mathrm{~m}$; average volume ( $\pm 1 \mathrm{SD})$ of $0.15 \pm 0.05$ vs. $0.06 \pm 0.02 \mathrm{~m}^{3}$. Nothofagus dombeyi showed similar cumulative growth in both conditions for all variables, but there was less variability and greater cumulative volume in the evergreen neighbourhood condition. Finally, Nothofagus obliqua showed similar cumulative growth in both conditions, for average diameter $( \pm 1 \mathrm{SD})(14.7 \pm 2.0 \mathrm{~cm})$ and average volume $( \pm 1 \mathrm{SD})(0.01 \pm$ $\left.0.03 \mathrm{~m}^{3}\right)$, but the average height $( \pm 1 \mathrm{SD})$ was significantly greater in the EN compared to DN (13.8 $\left.\pm 0.8 \mathrm{vs} .11 .2 \pm 0.9 \mathrm{~m}\right)$.

Conclusions: A suitable arrangement of mixed Nothofagus species plantations may deliver greater growth and productivity than pure plantations, or at least greater timber value considering that one species $(N$. dombeyi) usually surpasses the others in growth, but its timber is less valuable and its silviculture more costly. In these mixtures both facilitation and complementarity mechanisms occur, which was mostly expressed in the mid-tolerant $N$. alpina surrounded by the evergreen neighbourhood dominated by the shade-intolerant $N$. dombeyi. Our results provide new information relevant for the establishment of mixed plantations for production or restoration purposes. Both in Chile and Argentina, these three Nothofagus species cover extensive areas within the Valdivian Temperate Rainforests, so there is a great potential for these plantations in this or other regions with similar site conditions.
\end{abstract}

Keywords: Facilitation; biodiversity; cumulative growth; current annual increment; mean annual increment, mixed forests, hardwood plantations 


\section{Introduction}

Forest plantations are increasingly important to meet the present and future demands for wood and fibre, especially taking into account the growth of the world population and the continuous loss of natural forests (FAO 2016). Planted forests have increased by more than 105 million hectares since 1990 (FAO 2016), where $19 \%$ comprises exotic tree species for the regions where they are established (Brundu \& Richardson 2016). Chile is one of the 10 countries with more land allocated to forest plantations, and the fifth in America (Salas et al. 2016). However, in Chile this development is within the framework of an asymmetric forest model, with a strong plantation sector based on exotic tree species covering 2.9 million ha, while most non-protected native forests remain unmanaged or subjected to high-disturbance for firewood production (Donoso \& Otero 2005). This scenario has prompted the need to diversify the forest sector in Chile, especially with fast growing and highquality timber native species, among which those with the greatest interest include Nothofagus alpina (Poepp. \& Endl.) Oerst. Nothofagus dombeyi (Mirb.) Oerst. and Nothofagus obliqua (Mirb.) Oerst., all of which have good growth rates compared to other native tree species (Donoso \& Soto 2010), valuable timber (Hall \& Witte1998), and medium to high financial rates of return (Cubbage et al. 2007). These Nothofagus species are common within the Valdivian Temperate Rainforests of Chile and Argentina. These three species differ in several life history traits (Donoso 2013) and in their growth rates, which is especially greater for $N$. dombeyi (Donoso et al. 2015), but there are still few studies in Chile of plantations with these species established in open sites (Wienstroer et al. 2003, Donoso et al. 2015, Donoso \& Soto 2010), and to the best of our knowledge there is only one plantation with a mixed arrangement of Nothofagus species (Donoso et al. 2011).

Industrial forestry in Chile, and in general, encourages plantations as monocultures (Brundu et al. 2016) in coherence with an industrial logic, that is, one based on the paradigm that homogenization leads to economies of scale through reduction of factors and complexity in order to control an optimize variables under an efficiency-centred engineering approach (Lyle 1999). As mentioned above, the Chilean forest sector needs to move towards ending its an asymmetry between exotic forest plantations and native forests, and needs to have a strong economy related to native forests, which we believe should be mostly based upon mixed managed native forests and plantations of native species. Research has shown the advantages that can be obtained by using carefully designed species mixtures, which can be more biodiverse and can be more productive (Kelty 2006, Piotto 2008, Pretzch et al. 2017). In Chile, mixedspecies plantations have been suggested as a promising opportunity for native species (Donoso et al. 2011, Donoso et al. 2015, Uteau \& Donoso 2009), which is consistent with evidence accumulated elsewhere in the sense that well-planned mixed plantations have increased volume production and are more resilient and well adapted to the effects of climate change, in addition to maintaining other ecosystem services (Pretzsch et al. 2012, Lu et al. 2018, Vitali et al. 2018, Schnabel et al. 2019). The fact that diversity may have a positive effect on productivity, suggests a fundamental paradigm shift regarding the management of natural resources and forests. In contrast to the industrial model, an ecosystemic view of nature sees forests as living systems rather than biological machines, understanding that positive synergies can emerge from the various ecological interactions among the ecosystem components, most of them with non-linear dynamics (Capra 1997).

At least one or two important mechanisms are expected to occur in mixed plantations to achieve greater productivity: the complementary use of resources (light, soil and water) between species, which arises from the development of stratified vertical structures and possibly stratification of roots (Kelty 2006) and facilitation, which refers to the positive effect of certain plants on the establishment or growth of other plants (Yang et al. 2009). The selection and arrangement of tree species in these mixtures therefore is key to achieving greater productivity of the system or better growth of at least some of its species. In fact, that was the main hypothesis for the design of the plantation analysed in this work: that a mixed species plantation may exhibit advantages from the synergies emerged from its diversity. Such synergies were supposed to bring about higher production, resilience or other advantages.

Given these considerations, this work aimed to evaluate the growth in diameter, height and volume at the individual tree level of three Nothofagus species in a mixed plantation, considering two types of neighbourhoods, one comprised of deciduous tree species and another of only evergreen species. Our specific hypothesis in this study were that: a) the fastest growing $N$. dombeyi will be indifferent in its growth rates to its neighbouring environment, b) that growth of the mid-tolerant and deciduous $N$. alpina will be facilitated by an evergreen neighbourhood, and c) that growth of the shade-intolerant and deciduous $N$. obliqua will be negatively affected by an evergreen neighbourhood. We contrast results to these hypotheses, including the possible effects of niche complementarity.

\section{Methods}

\section{Study site}

The study was conducted in a private rural property (Curileufu) agricultural-forestry site in the Andes foothills near the Ranco lake (40²2'57'S-72 30'41"W) at an elevation of $400 \mathrm{~m}$ a.s.l. in Los Ríos Region (Chile). Climate is temperate rainy with Mediterranean influence, with annual average temperatures of $10.2^{\circ} \mathrm{C}$, annual precipitation $2181 \mathrm{~mm}$ according to agroclimatic stations, and with a period of 213 days without frosts (CIREN 1990). The soil series corresponds to Puerto Fonk, within the mesic family of Andisols. Soils are deep ( $>1 \mathrm{~m}$ ) and formed from volcanic ash deposits. They are characterized by a loamy-silty surface texture with a slightly undulating topography (slopes of 2 to 5\%) to hills with slopes of 30 to $50 \%$ (CIREN 2003). The 
plantation was established on gentle slopes $(<15 \%)$ (Fig. 1). As suggested by regional site evaluations that have been conducted by several authors in secondary forests of Nothofagus species (Donoso et al. 1993a, Echeverría \& Lara 2004, Esse et al. 2013), the site of this study should be suitable for growing plantations of these species, e.g., the mid-elevation region of south-central Chile between latitude 38 and $41^{\circ} \mathrm{S}$.

The study site corresponds to 25 ha of mixed species plantation established in 2001, with different native species. When these plantations were 18 years old (2019), they were systematically sampled with fifteen $400 \mathrm{~m}^{2}$ forest inventory plots. The sample means $( \pm$ $1 \mathrm{SD}$ ) for the plots were $1,560 \pm 255$ trees ha ${ }^{-1}, 28.4 \pm$ $4.8 \mathrm{~m}^{2} \mathrm{ha}^{-1}$ basal area, $133 \pm 23 \mathrm{~m}^{3} \mathrm{ha}^{-1}$ in volume, and a quadratic stem diameter at breast height of $15.3 \pm 2.2$ $\mathrm{cm}$. These plantations are dominated by $N$. dombeyi, $N$. obliqua, N. alpina and Embothrium coccineum J.R.Forst. \& G.Forst. (Fig. 2).

The plantation was established under a forest system with adherence to natural processes (Siebert 2006). Among other characteristics, this system corresponds to a matrix of highly valuable timber species with other pioneer shrub and short-lived tree species, with the aims of: 1) reducing the vigour of competing grassland; 2) favouring etiolation by density; 3 ) increasing the diversity of species and the ecosystem functions of the future forest; and 4) reducing the cost of purchasing seedlings and thinning. Also, the plantation design was made following a landscape ecology approach (Schillessi et al. 2017), including the design of biological corridors between distant forests patches (Fig. 1).
The plantation used 14 native pioneer species, but was dominated by only six species, three valuable timber Nothofagus species ( $N$. obliqua, $N$. alpina and $N$. dombeyi), one long-lived species (Drimys winteri J.R.Forst \& G.Forst.), one short-lived tree species (Embothrium. coccineum), and one short-lived small tree species (Aristotelia chilensis (Molina) Stuntz). One- or two-yearold bare-rooted seedlings $50-150 \mathrm{~cm}$ in height were preferred (from consolidated local nurseries), many of them with root pruning. Seedlings of these species were planted during winter of 2001 , at a distance of $2 \times$ $2.5 \mathrm{~m}$, alternating species through the plantation row in a sequential scheme as follows: $N$. obliqua - other sp. - $N$. alpina - other sp. - N. dombeyi - other sp., where 'other sp.' refers to any other pioneer species. Every row was planted following the same set and independent of its neighbour rows.

\section{Silvical characteristics for the three Nothofagus species}

These three Nothofagus species differ in several ecological characteristics (Donoso 2013). N. alpina is a mid-tolerant, deciduous and deep-rooted species. It has a restricted distribution compared with $N$. dombeyi and N. obliqua, mostly in the Andes Mountains at elevations from 400 to $1200 \mathrm{~m}$, in regions with abundant rainfall ( $>1300 \mathrm{~mm}$ per year). $N$. dombeyi is a shade-intolerant pioneer species, evergreen and shallow-rooted, with a wide geographical distribution from 30 to $47^{\circ} \mathrm{S}$, from sea level to $1200 \mathrm{~m}$. N. obliqua is also a pioneer shadeintolerant species, but deciduous and deep-rooted, and grows in both the Andes and the Coastal ranges and in the

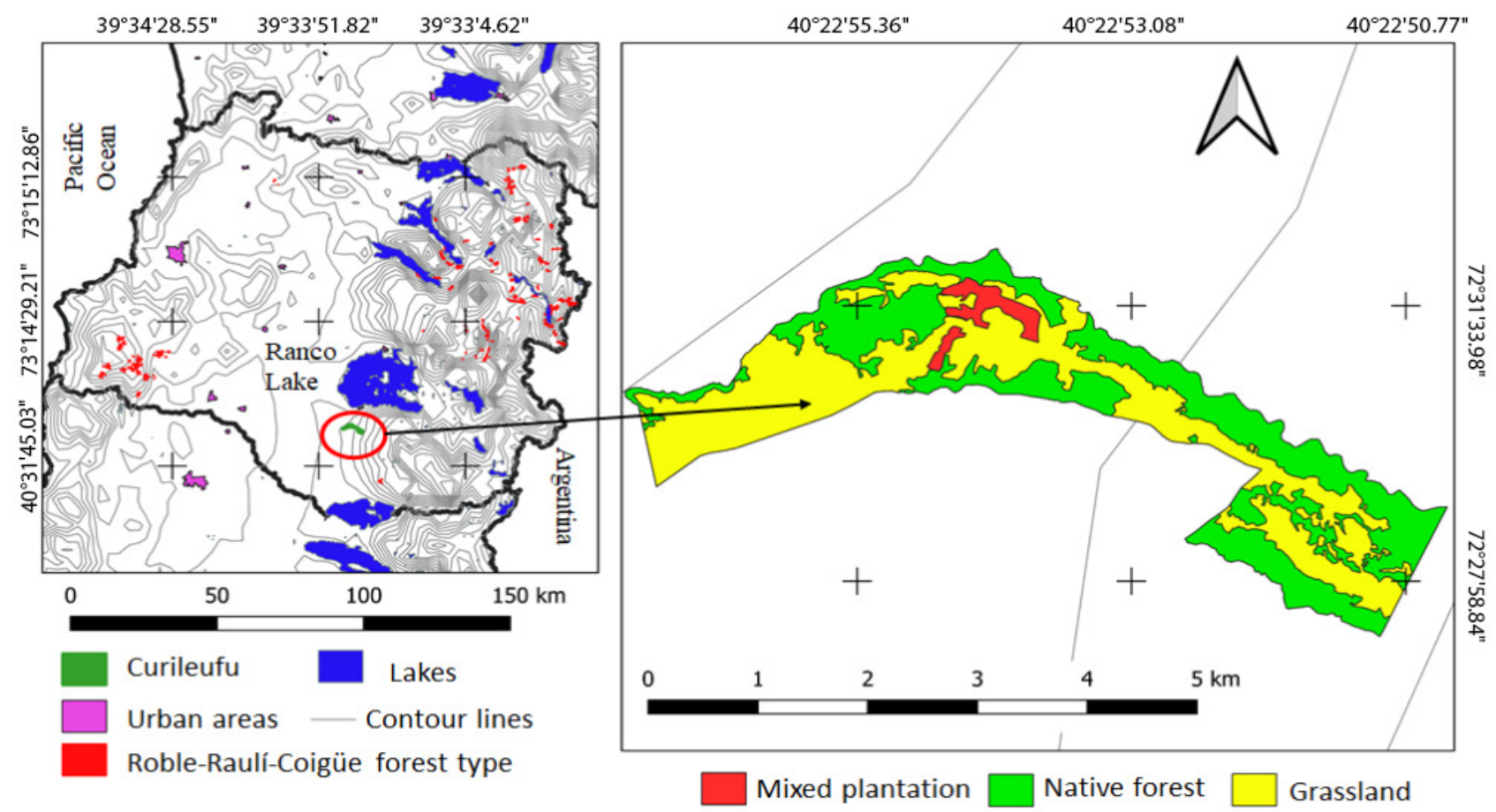

FIGURE 1: Map of the Curileufu property where the mixed plantation was established in the Andean foothills of southcentral Chile (left) and of land uses within the property, including the area of the mixed plantations (right). 


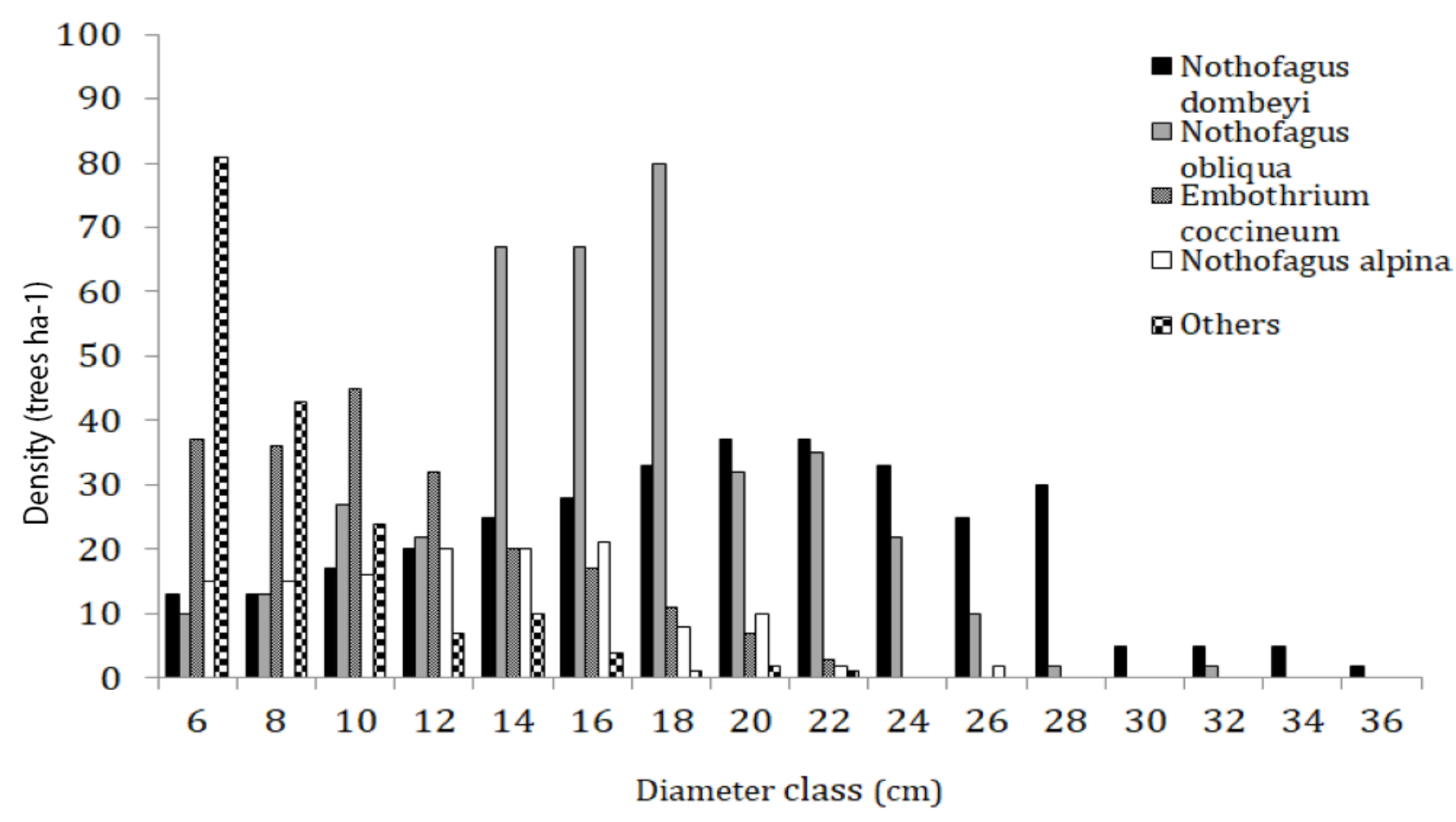

FIGURE 2: Diameter distribution of the main tree species in the mixed plantation.

Intermediate Depression, but in south-central Chile only to elevations below $600 \mathrm{~m}$, in areas with average annual temperatures above $10^{\circ} \mathrm{C}$, preferring climatic conditions with Mediterranean influence. All these species have rapid growth rates, but $N$. dombeyi is usually the fastest both in secondary forests and in plantations (Donoso et al. 1993a, Donoso et al. 1993b, Donoso et al. 2013, Donoso et al. 2015, Grosse \& Quiroz 1999, Wienstroer et al. 2003, Echeverría \& Lara 2004, Donoso et al. 2011).

\section{Variables measured and competition index}

To test the growth of individual trees, we selected 10 trees from each species that had to be dominant or codominant, with no apparent damage and straight stems (sensu Wienstroer et al. 2003). For each species, five trees were selected with a deciduous neighbourhood (DN) and five with an evergreen neighbourhood (EN). Neighbourhoods were classed as DN or EN, based on the classification (deciduous or evergreen respectively) of at least $90 \%$ of the basal area of individual trees in the neighbourhood of the subject tree. Deciduous competing species were $N$. alpina and $N$. obliqua; evergreen competing species were mostly $N$. dombeyi and in few cases $E$. coccineum, which occupied mostly intermediate and codominant canopy positions (Fig. 2).

Each subject tree was harvested in 2019 and crosssections of the stems were removed at different heights to conduct a stem analysis of the tree. Cross-sections were taken at the stump level $(0.3 \mathrm{~m})$, breast height $(1.3 \mathrm{~m})$, and then every $1 \mathrm{~m}$ up to the apex of the tree as recommended by Salas (2011). A total of 135 crosssections were measured for N. alpina, 108 for N. obliqua and 127 for $N$. dombeyi. Furthermore, the diameter at breast height (d) and total height ( $h$ ) of each subject tree were measured.

All cross-sections were taken to the lab where they were dried and sanded using sandpaper of increasingly finer grain following the techniques outlined in Stokes and Smiley (1968). Although we did not measure wood shrinkage, Díaz-Vaz et al. (2002) indicate that shrinkage for these three species is less than $10 \%$. Then, they were scanned and analysed with the Windendro ${ }^{\circledR}$ software to quantify the number of rings and growth in each year following Schulman's (Schulman 1956) convention for the Southern Hemisphere, which assigns to each tree ring the date of the calendar year in which tree growth started. The stem analyses were carried out with the WinStem ${ }^{\circledR}$ software, generating the diameter, height and volume (v) for each tree and year of growth.

To evaluate whether differences in growth occurred due to the evergreen or deciduous neighbourhood, rather than to other competition variables (such as diameters and distances of neighbour trees), we used the Iterative Hegyi Index (ITH), where we recorded the species, azimuth and distance to the subject tree of all trees in a $7.5 \mathrm{~m}$ radius competition zone (since the index after that distance remains constant according to Lendermann and Stage (2001). This index determines the active competing trees within a competition zone, taking into account the diameter of the subject tree and the diameter and distance of each competing tree. An active competitor is a neighbour of the subject tree that meets two conditions: a) must have a minimum size; and b) must be a direct neighbour (Lee et al. 2004, Seifert et 
al. 2014). There were no significant differences between the indices (ITH) for any species according to the neighbourhood: ( N. alpina, P-value $=0.966 ; N$. obliqua, $\mathrm{P}$-value $=0.900 ; N$. dombeyi, $\mathrm{P}$-value $=0.660($ Table 1$)$ ). The equation of ITH is:

$$
\mathrm{ITH}=\sum_{j=1}^{n}\left(\frac{d_{j}}{d_{i}} \frac{1}{\operatorname{DIST}_{i j}}\right) \quad \text { and } i \neq j
$$

Where: $i=$ refers to the reference tree and $j$ to the competitor; $d$ to breast height diameter $(\mathrm{cm})$ and DIST $_{i j}$ to the distance between tree $i$ and its competitor tree $j$.

\section{Statistical analyses}

We fitted nine non-linear mixed-effects models, by adding random effects to the $\alpha$ and $\beta$ parameters using the nlme package (Pinheiro et al. 2017) in R (R Core Team 2017). The Richards model (Richards 1959) was used to fit three models for cumulative growth $(d, h, v)$ for all subject trees $(n=30)$ according to age:

$$
\mathrm{y}_{i j k l}=\alpha+\alpha_{i j k}\left(1-\mathrm{e}^{-\beta+\beta_{i j k} * \mathrm{t}_{i j k l}}\right)^{\gamma}+\varepsilon_{i j k l}
$$

$\alpha_{i j k} \sim N\left(0, \sigma^{2}{ }_{a}\right) ; \beta_{i j k} \sim N\left(0, \sigma^{2}{ }_{b}\right) ; \varepsilon_{i j k l} \sim N\left(0, \sigma^{2}{ }_{\varepsilon}\right)$

where: $\mathrm{y}_{i j k l}=$ is the diameter $(\mathrm{cm})$ or height $(\mathrm{m})$ or volume $\left(\mathrm{m}^{3}\right)$ for the $i^{\text {th }}$ object tree within the $j^{\text {th }}$ species within the $k^{\text {th }}$ neighbourhood at the $l^{\text {th }}$ time; $\alpha, \beta$ and $\gamma=$ are parameters; $\alpha_{i j k^{\prime}} \beta_{i j k}=$ are random effects at the tree level within the species within each neighbourhood; $t_{i j k l}$ $=$ age of growth for the $i^{\text {th }}$ object-tree according the $j^{\text {th }}$ species within the $\mathrm{k}^{\text {th }}$ neighbourhood in $I^{\text {th }}$ time; $\varepsilon_{i j k l}=$ random model error

Then, the first derivative of the Richards function was used to fit three more models for the current annual increment (CAI) in $d, h$ and $v$ for all subject-tree $(n=30)$ according to age:

$$
\begin{gathered}
\mathrm{y}_{i j k l}=\alpha+\alpha_{i} * \beta+\beta_{i} * \gamma *\left(1-\mathrm{e}^{-\beta+\beta_{i} * \mathrm{t}_{i j k l}}\right)^{\gamma} \\
* \mathrm{e}^{-\beta+\beta_{i} * \mathrm{t}_{i j k l}}+\varepsilon_{i j k l}
\end{gathered}
$$

where $\mathrm{y}_{i j k l}=$ is the CAI in diameter $\left(\mathrm{cm}\right.$ year $\left.{ }^{-1}\right)$ or height (m year ${ }^{-1}$ ) or volume $\left(\mathrm{m}^{3}\right.$ year $\left.{ }^{-1}\right)$ for the $i^{\text {th }}$ object-tree within the $j^{\text {th }}$ species within the $k^{\text {th }}$ neighbourhood in $l^{\text {th }}$ time; all other parameters are defined as for Eq. 1.

Finally, three models were fitted to obtain the mean annual increment (MAI) in $\mathrm{d}, \mathrm{h}$ and $\mathrm{v}$ for all object-tree $(n=30)$ according to age:

$$
\mathrm{y}_{i j k l}=\frac{\alpha+\alpha_{i}\left(1-\mathrm{e}^{\left.-\beta+\beta_{i} * t_{i j k l}\right)^{\gamma}}+\varepsilon_{i j k l}\right.}{\mathrm{t}_{i j k l}}
$$

\begin{tabular}{|c|c|c|c|c|c|c|c|}
\hline Species & Neighbourhood & Variable & Min. & Max. & Median & Mean & CV (\%) * \\
\hline \multirow{6}{*}{$\begin{array}{l}\text { Nothofagus } \\
\text { alpina }\end{array}$} & \multirow{3}{*}{$\begin{array}{l}\text { Evergreen } \\
n=5\end{array}$} & $\mathrm{~d}(\mathrm{~cm})$ & 13.7 & 17.4 & 15.1 & 15.3 & 8.9 \\
\hline & & $\mathrm{h}(\mathrm{m})$ & 13.3 & 17.7 & 16.1 & 15.5 & 11.5 \\
\hline & & ITH & 1.9 & 2.5 & 2.3 & 2.2 & 11.1 \\
\hline & \multirow{3}{*}{$\begin{array}{l}\text { Deciduous } \\
\mathrm{n}=5\end{array}$} & $\mathrm{~d}(\mathrm{~cm})$ & 8.9 & 13.2 & 10.5 & 11.1 & 18.2 \\
\hline & & $\mathrm{h}(\mathrm{m})$ & 11.4 & 14.0 & 13.6 & 13.7 & 7.8 \\
\hline & & ITH & 1.5 & 2.6 & 2.4 & 2.2 & 19.3 \\
\hline \multirow{6}{*}{$\begin{array}{l}\text { Nothofagus } \\
\text { obliqua }\end{array}$} & \multirow{3}{*}{$\begin{array}{l}\text { Evergreen } \\
n=5\end{array}$} & $\mathrm{~d}(\mathrm{~cm})$ & 11.6 & 16.9 & 15.1 & 14.7 & 13.5 \\
\hline & & $\mathrm{h}(\mathrm{m})$ & 12.6 & 14.8 & 13.8 & 13.8 & 5.8 \\
\hline & & ITH & 1.6 & 2.5 & 1.8 & 1.9 & 19.4 \\
\hline & \multirow{3}{*}{$\begin{array}{l}\text { Deciduous } \\
\mathrm{n}=5\end{array}$} & $\mathrm{~d}(\mathrm{~cm})$ & 12.4 & 17.3 & 15.4 & 15.2 & 11.5 \\
\hline & & $\mathrm{h}(\mathrm{m})$ & 10.5 & 12.7 & 10.8 & 11.2 & 8.3 \\
\hline & & ITH & 1.6 & 2.5 & 1.9 & 1.9 & 21.9 \\
\hline \multirow{6}{*}{$\begin{array}{l}\text { Nothofagus } \\
\text { dombeyi }\end{array}$} & \multirow{3}{*}{$\begin{array}{l}\text { Evergreen } \\
n=5\end{array}$} & $\mathrm{~d}(\mathrm{~cm})$ & 21.4 & 26.7 & 22.5 & 23.3 & 7.8 \\
\hline & & $\mathrm{h}(\mathrm{m})$ & 13.3 & 15.1 & 14.7 & 14.5 & 4.8 \\
\hline & & ITH & 0.9 & 1.3 & 1.1 & 1.1 & 13.9 \\
\hline & \multirow{3}{*}{$\begin{array}{l}\text { Deciduous } \\
\mathrm{n}=5\end{array}$} & $\mathrm{~d}(\mathrm{~cm})$ & 13.0 & 28.4 & 25.5 & 22.3 & 28.3 \\
\hline & & $\mathrm{h}(\mathrm{m})$ & 12.9 & 16.0 & 14.0 & 14.2 & 7.9 \\
\hline & & ITH & 1.0 & 1.5 & 1.2 & 1.2 & 16.4 \\
\hline
\end{tabular}

where $\mathrm{y}_{i j k l}=$ is the diameter $(\mathrm{cm})$ or height $(\mathrm{m})$ or volume

TABLE 1: Descriptive statistics of subject trees and competition index (ITH) according to the neighbourhood for each species at age 18. 
$\left(\mathrm{m}^{3}\right)$ for the $i^{\text {th }}$ object-tree within the $j^{\text {th }}$ species within the $k^{\text {th }}$ neighbourhood in $l^{\text {th }}$ time; all other parameters are defined as for Eq. 1.

We used the Akaike's Information Criterion (AIC) for each model (Equations 2-4) applied for each dependent variable $(d, h$ or $v)$ to compare the importance of the neighbourhood effect in each model, according to three levels of nesting data: for tree level (first level), the tree within in the neighbourhood (second level) and the tree within the specie within the neighbourhood (third level).

The best models according to AIC were further evaluated using: The root mean square differences (RMSD), the aggregated differences (DA), and the mean absolute difference (DAA). Finally, for a more accurate comparison of the neighbourhood effect for each specie, we computed confidence intervals (CI) for each model (using the estimated variance components from the mixed-effects models), using a significance level of 0.05 , and identified significant differences by non-overlapping confidence intervals for each age.

\section{Results}

The best models were those where the neighbourhood variable (in addition to the species) was included in the nested structure of the data (Table 2), and were selected according to the AIC.

The RMSD for the cumulative growth models (Equation 1) had an error below $6.5 \%$ and a bias (DAA) lower than $5 \%$ (Table 3), which indicates that they are very reliable models (typical of stem analysis). On the contrary, the curves for current annual increment (Equation 3) had an error between 20 and 40\% (RMSD), and a bias (DAA) between 17 and 32\%, reason why confidence intervals (CI) were too wide. Finally, the curves for mean annual increment (Equation 4) had errors between 7 and 19\% (RMSD) and bias (DAA) between 5 and 19\%.

Nothofagus alpina showed significantly greater cumulative growth in all variables $(d, h$ and $v)$ when growing in an evergreen neighbourhood (EN) (Figure 3A; Additional File: Table S1). According to the confidence intervals, from the seventh year on significant differences occurred in cumulative diameter, from the fourth year for cumulative height, and from the ninth year for cumulative volume. At the age of 18 years, the average diameter $( \pm 1 \mathrm{SD})$ of $N$. alpina was $15.3 \pm 1.4 \mathrm{~cm}$ at EN and $10.8 \pm 2.0 \mathrm{~cm}$ at $\mathrm{DN}$; average height $( \pm 1 \mathrm{SD})$ was $15.5 \pm 1.8 \mathrm{~m}$ at EN vs. $13.2 \pm 1.0 \mathrm{~m}$ at $\mathrm{DN}$; average volume $( \pm 1 \mathrm{SD})$ was $0.15 \pm$ $0.05 \mathrm{~m}^{3}$ at EN vs. $0.06 \pm 0.02$ at DN.

Nothofagus dombeyi showed similar cumulative growth in both neighbourhood conditions (EN and DN) (Figure 3B). However, according to the confidence intervals (Additional File: Table S2), there were significant differences in the mean annual increment in diameter and height from the third to the tenth year approximately. The above generated less variability and a greater cumulative volume $( \pm 1 \mathrm{SD})$ in EN $(0.31 \pm 0.07$ $\left.\mathrm{m}^{3}\right)$ compared to DN at age $18\left(0.25 \pm 0.12 \mathrm{~m}^{3}\right)$.

Nothofagus obliqua showed similar cumulative growth in both conditions (EN and DN) at age 18. However, according to the confidence intervals, there were significant differences in cumulative height from the sixth year onwards, with a cumulative height ( \pm SD) of $13.8 \pm 0.8 \mathrm{~m}$ in EN vs. $11.2 \pm 0.9 \mathrm{~m}$ in DN at age 18 (Figure 3C; Additional File: Table S3).

Annual increments showed both similarities and differences among species (Figure 4, Additional File: Tables S1-S3). Nothofagus alpina showed significantly greater growth in the EN condition, e.g. the MAI in diameter $( \pm 1 \mathrm{SD})$ was $0.85 \pm 0.08$ at EN vs. $0.60 \pm 0.11$

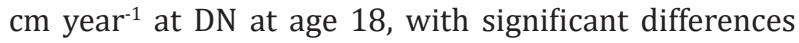
occurring after year six. For height, the difference between both neighbourhood conditions occurred right from the start and was sustained until the end of the period assessed. For volume, the difference between EN and DN was evidenced after the ninth year (Figure 4A, Table S1). Nothofagus dombeyi had greater growth rates in diameter and height during the first seven years when comparing EN with DN (Figure 4B, Table S2). Therefore, in pure conditions, $N$. dombeyi tended to accumulate more volume and less variability. For $N$. obliqua, the CAI and MAI curves (Figure 4C,) in diameter and volume were very similar in both neighbourhood conditions, but the growth in height was much higher in the EN condition from the fourth year onwards (Table S3).

TABLE 2: Akaike's information criterion (AIC) for each model (Equation [2], [3] or [4]) applied for each dependent variable ( $\mathrm{d}, \mathrm{h}$ or $\mathrm{v}$ ), according to three levels of nested-data: Only trees (1st level), the trees within in the neighbourhood (2nd level) and the trees according to the species within the neighbourhood (3rd level).

\begin{tabular}{|c|c|c|c|c|c|c|c|c|c|}
\hline \multirow[b]{2}{*}{ Level } & \multicolumn{3}{|c|}{$\begin{array}{c}\text { Eq. [2] Cumulative growth } \\
\text { curves }\end{array}$} & \multicolumn{3}{|c|}{$\begin{array}{l}\text { Eq. [3] Curves for current annual } \\
\text { increment }\end{array}$} & \multicolumn{3}{|c|}{$\begin{array}{l}\text { Eq. [4] Curves for mean annual } \\
\text { increment }\end{array}$} \\
\hline & $\begin{array}{l}\text { Diameter } \\
\text { (d) }\end{array}$ & $\begin{array}{l}\text { Height } \\
\text { (m) }\end{array}$ & $\begin{array}{l}\text { Volume } \\
\left(\mathrm{m}^{3}\right)\end{array}$ & $\begin{array}{l}\Delta \mathrm{d} \\
\left(\mathrm{cm} \text { year }^{-1}\right)\end{array}$ & $\begin{array}{l}\Delta \mathrm{h} \\
\left(\mathrm{m} \text { year }^{-1}\right)\end{array}$ & $\begin{array}{l}\Delta v \\
\left(m^{3} \text { year }^{-1}\right)\end{array}$ & $\begin{array}{l}\Delta \mathrm{d} \\
\left(\mathrm{cm} \operatorname{year}^{-1}\right)\end{array}$ & $\begin{array}{l}\Delta \mathrm{h} \\
\left(\mathrm{m} \text { year }^{-1}\right)\end{array}$ & $\begin{array}{l}\Delta v \\
\left(\mathrm{~m}^{3} \text { year }^{-1}\right)\end{array}$ \\
\hline $1 s t$ & 959.03 & 946.2 & $-4,505.9$ & 692.3 & 433.6 & $-4,594.6$ & $-1,456.4$ & $-1,034.3$ & $-6,211.8$ \\
\hline 2nd & 965.03 & 946.5 & $-4,499.9$ & 698.3 & 432.3 & $-4,588.6$ & $-1,450.9$ & $-1,036.3^{*}$ & $-6,211.8^{*}$ \\
\hline $3 r d$ & $948.52 *$ & $940.6^{*}$ & $-4,506.6^{*}$ & $681.2^{*}$ & $432.1^{*}$ & $-4,603.9 *$ & $-1,468.8^{*}$ & -269.2 & $-6,207.7$ \\
\hline
\end{tabular}

* Best option according Akaike's information criterion (AIC). 


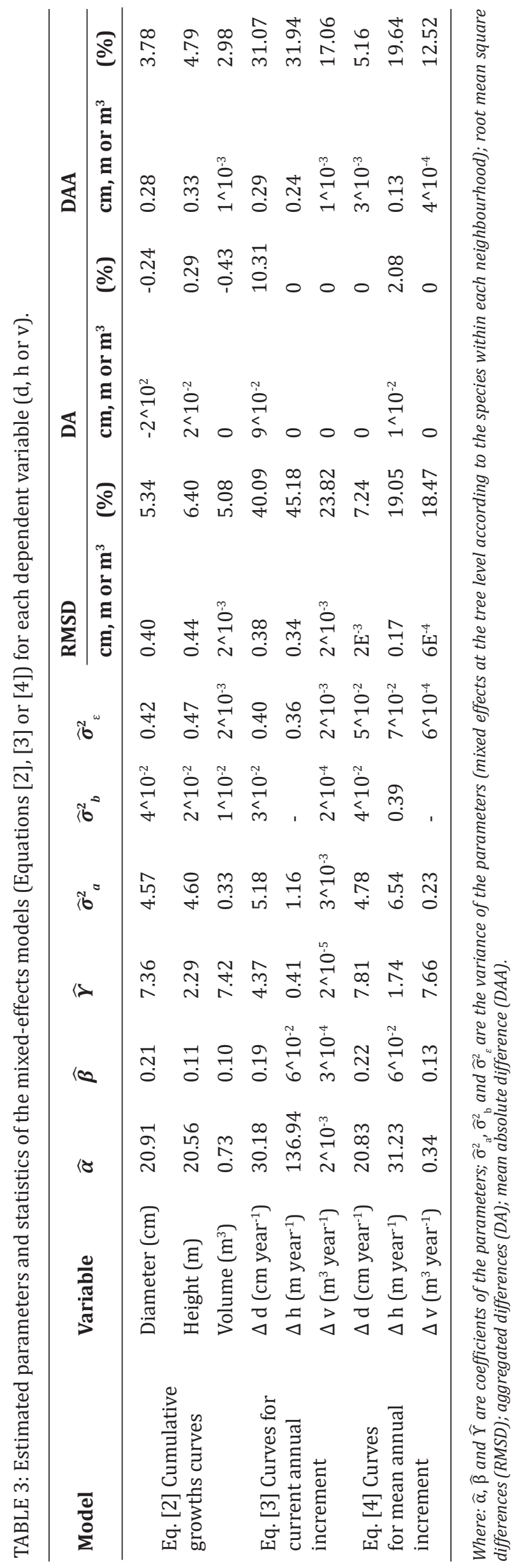

\section{Discussion}

\section{Comparative growth rates of Nothofagus species}

Not many reported studies exist about plantations of Nothofagus species in Chile, although Donoso et al. (2015) published a handbook for $N$. alpina and $N$. dombeyi plantations where they compiled what was known up to that year. In that work, Donoso et al. (2015) provided proposals for silvicultural systems for each species, with rotations of 30-35 years where the average diameter growth would be close to $1 \mathrm{~cm}$. The growth rates obtained in the present study have been lower than this at least during the first 18 years, although theoretically the site should be well suited for the three Nothofagus species evaluated. We believe that a main reason for these results is that the plantation site was previously used, for decades, as a pasture for bovines, so that the soil was likely to be compacted in the upper horizons. The fact that plantation growth was much slower during the first five years might have been the result that during those years the root systems had difficulties to grow, expand and supply abundant water and nutrients to the young trees. Donoso et al. (2011) also reported low growth rates for a 7-yearold $N$. alpina and $N$. dombeyi plantation in the Andes at $500 \mathrm{~m}$ elevation, further north, in a site that had been a pasture for bovines before. Donoso et al. (2015) found that growth rates were greater between ages 9 to 13 , suggesting that the negative soil compaction effect upon growth caused by bovines, seemed to be surpassed after approximately five years, once the roots reached deeper soil horizons.

Growth of $N$. alpina in the EN condition was similar to those reported in good sites in diameter and height in other plantations in the Andes (Donoso et al. 1993, Wienstroer et al. 2003), i.e. a MAI in diameter ( \pm 1SD) of $0.85 \pm 0.08 \mathrm{~cm}$, and a MAI in height ( $\pm 1 \mathrm{SD}$ ) of 0.86 $\pm 0.1 \mathrm{~m}$ at age 18 years. Diameter growth for $N$. obliqua was lower than those reported by Donoso et al. (1993b) also in the Andes but further north, and was indifferent to neighbourhood (interspecific or intraspecific competition), but there were differences in height growth according to the neighbouring trees, with better growth in the EN. Growth in diameter and height of $N$. dombeyi was indifferent to neighbourhood conditions, and was similar to those reported in good sites in the Andes (Donoso et al. 1993b, 2015), with a MAI in diameter $( \pm 1 \mathrm{SD})$ of $1.29 \pm 0.1 \mathrm{~cm}^{\text {year }}{ }^{-1}$ and in height $( \pm 1 \mathrm{SD})$ of $0.80 \pm 0.04 \mathrm{~m}$. These results illustrate that $N$. dombeyi did not seem to be affected in its growth rates as much as the other species did, reflecting its greater plasticity to a diversity of site conditions (Donoso et al. 2015).

The plantation under study had an average volume of $133 \mathrm{~m}^{3} \mathrm{ha}^{-1}$, indicating that at 18 age it had a MAI of $7.4 \mathrm{~m}^{3} \mathrm{ha}^{-1}$ year $^{-1}$. This growth rate is lower than those observed for most pure Nothofagus plantations in Chile (Donoso et al. 1993b). It is also lower compared with some mixed plantations elsewhere, such as in mixed plantations in Europe (Pretzsch et al. 2017) which have a 


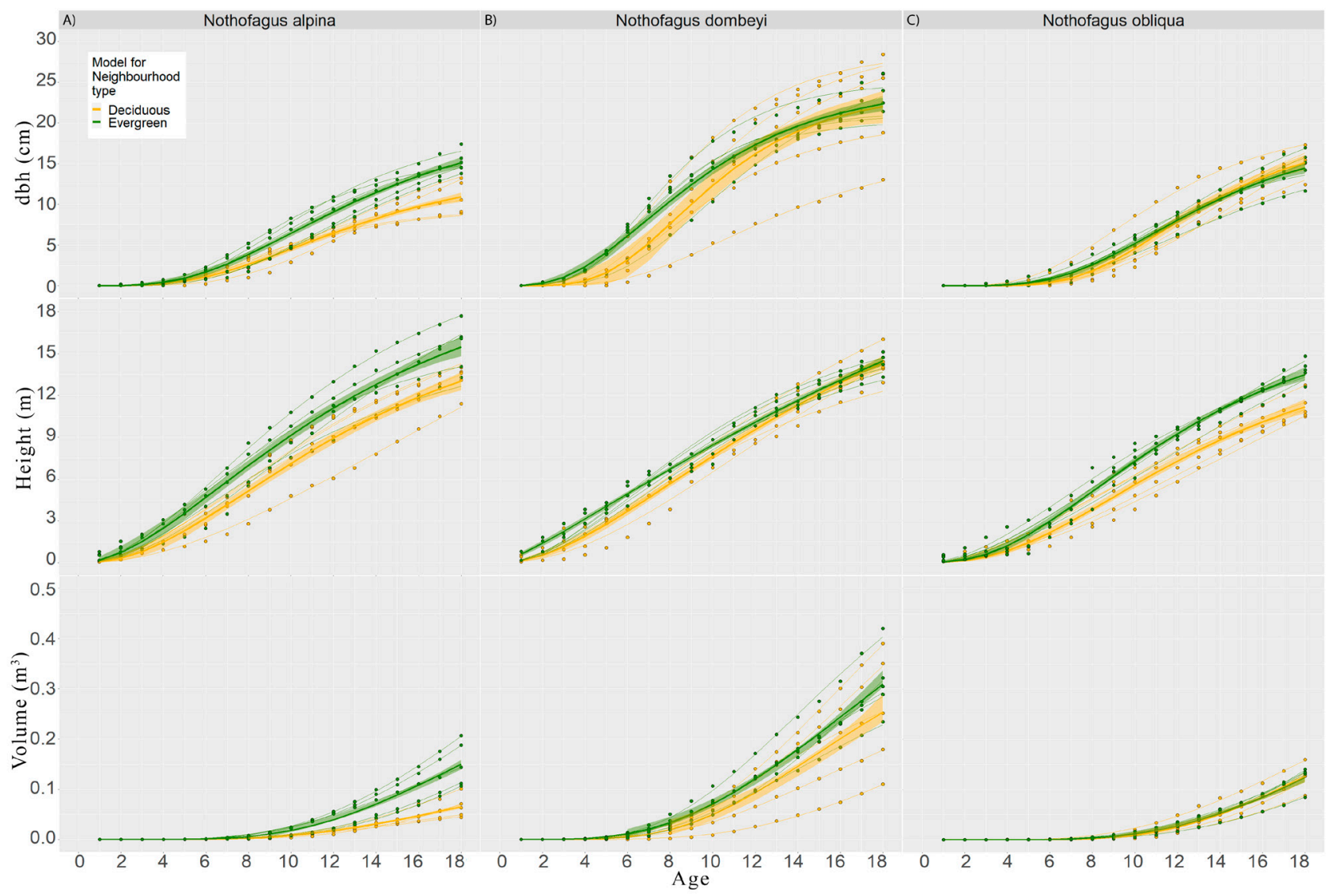

FIGURE 3: Cumulative growth curves (Equation 2) in d, h and v for each Nothofagus species (A,B,C) growing with two types of neighbour competition (deciduous or evergreen). Thick lines represent the modelled growth by all trees according to condition, thin lines represent growth of individual trees. The hatched area in each curve are the confidence intervals with a significance level of $0.05 \%$.

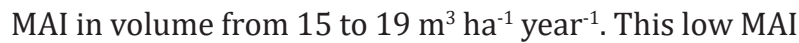
in this mixed Nothofagus spp. plantation was the result of slow growth during the first five years. After age 5 , the plantation had a MAI near $15 \mathrm{~m}^{3} \mathrm{ha}^{-1}$ year $^{-1}$. Therefore, this illustrates the need to continue evaluating these mixed plantations under different site conditions.

\section{Interspecific vs intraspecific competition and the interpretation of facilitation and complementarity mechanisms}

The three species, with different silvical characteristics, showed different responses in growth according to their neighbourhoods. Growth in diameter, height and volume was higher with an evergreen neighbourhood in N. alpina (mid-tolerant, deciduous, deep-rooted). In contrast $N$. dombeyi (shade-intolerant, evergreen, shallow root) was not responsive to the type of neighbourhood, and $N$. obliqua (shade-intolerant, deciduous, deep-rooted) was in an intermediate position, with greater growth only in height in evergreen neighbourhoods.

Nothofagus alpina was the species most favoured in its growth by having an evergreen neighbourhood. While we cannot partition whether this was a result due to facilitation or niche complementarity, we believe that both mechanisms operated. It is well known that
N. alpina prefers some shelter to grow better especially during early stages of development (Donoso et al. 2013,2015), and Donoso et al. (2011) already reported that a neighbourhood of $N$. dombeyi facilitated growth of $N$. alpina in northern aspects, which coincides with our results.

The facilitation mechanism (sensu Vandermeer 1992) operates especially in terms that evergreen species may moderate microclimate. In colder seasons the facilitation of deciduous species from evergreen species could have taken place in several forms: lower exposition to cold winds during winter, abundant and constant supply of organic matter whose decomposition generates heat, and the presence of a evergreen canopy that ameliorates the effects of frosts and reduces the escape of longwave radiation (heat). During the growing season the facilitation of $N$. dombeyi towards $N$. alpina is not explained by its evergreen character, since $N$. alpina is also leafed, but likely because of its higher growth rates that generate a partial shade upon $N$. alpina seedlings or trees that favours the growth of the later (Donoso et al. 2011). The higher growth and very high foliar area of $N$. dombeyi allows less direct light (radiation), lower range of temperatures and greater relative humidity, where temperatures and evapotranspiration are greater than in south aspects in the southern hemisphere in the 


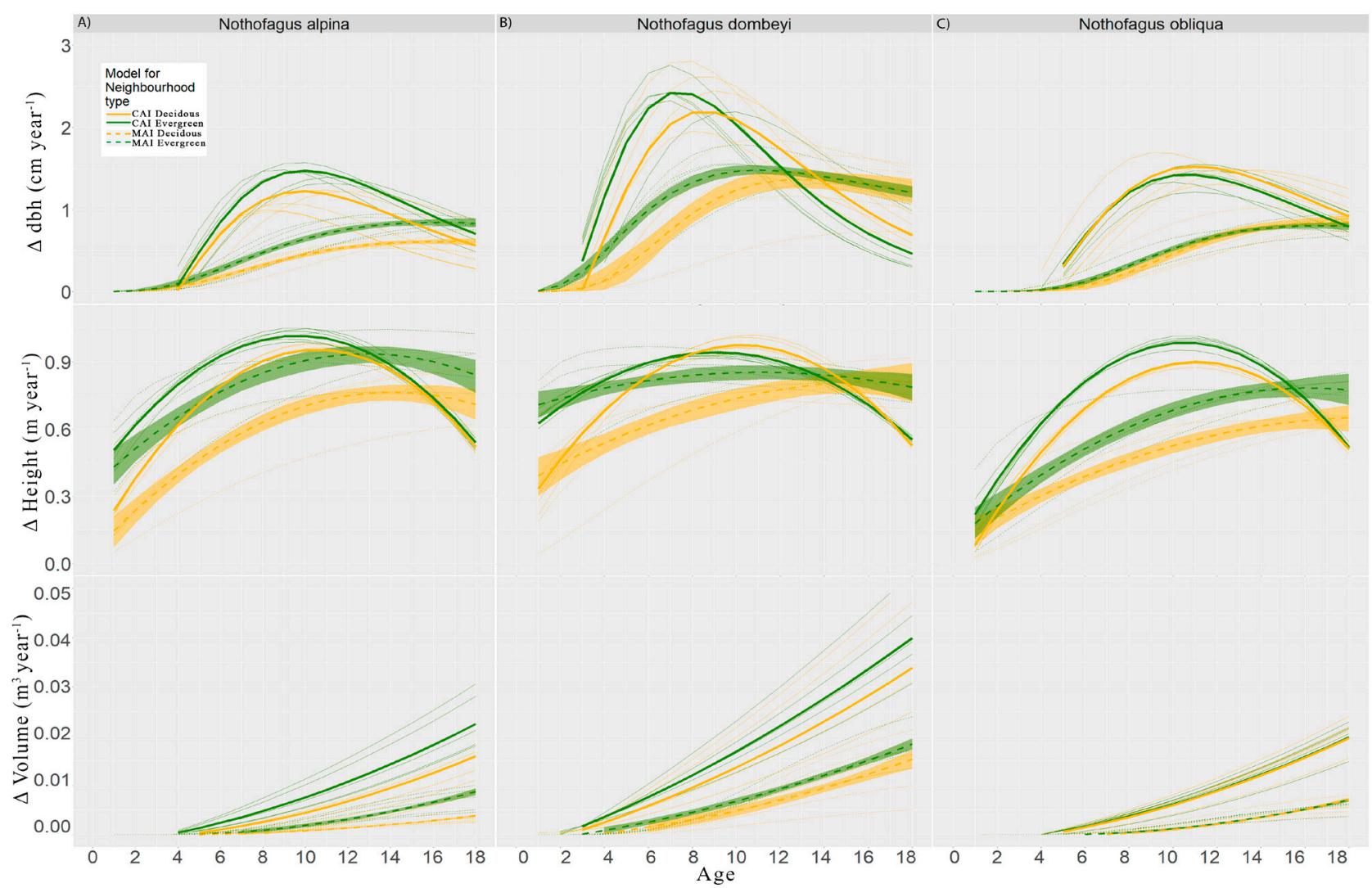

FIGURE 4: Curves for current annual increment (CAI) and mean annual increment (MAI) (Equations 3 and 4) for each Nothofagus species $(\mathrm{A}, \mathrm{B}, \mathrm{C})$ under the two types of neighbour competition evaluated. Thick lines represent the modelled growth by all trees according to condition, Thin lines represent growth of individual trees. The hatched area in each curve corresponds to the confidence intervals with a significance level of $0.05 \%$.

microenvironment surrounding the species of interest, especially during the first years after establishment. Finally, there might be also other complex ecological interactions (Elíades et al. 2019), such as mycorrhizal or entomological synergies. These issues deserve further ecological studies.

In terms of whether niche complementarity might also have operated here, we think that the results for $N$. obliqua provide some insights for interpretation. Two shade-intolerant species planted together (mixed), such as $N$. dombeyi and N. obliqua, should naturally compete, and $N$. obliqua should be disfavoured in this case (lower growth rates). However, height growth of $N$. obliqua with an evergreen neighbourhood ( $N$. dombeyi) was significantly greater with an evergreen neighbourhood than when competing with a deciduous neighbourhood. While among the three Nothofagus species we evaluated, $N$. obliqua is in general the best adapted to relatively dryer environments (Donoso 2003), supposedly being indifferent to north or south aspects in southern Chile, the expected high water competition between $N$. dombeyi and N. obliqua in north aspects may have been tempered by the differential rooting patterns of both species (shallower in N. dombeyi and deeper in $N$. obliqua), hence developing niche complementarity. This might also have occurred with $N$. alpina that has a deep rooting system similar to that of $N$. obliqua.

\section{Implications for management of mixed plantations}

All Nothofagus species evaluated in this study exhibited high growth rates after approximately the initial five years of slow growth, and the two deciduous Nothofagus were positively affected when combined with the evergreen Nothofagus, although to different extents. Results reflect that mixtures can be successful, but appropriate species selection and initial arrangements, and further silvicultural prescriptions need to be considered in order to maintain the positive effects of facilitation and niche complementarity that can occur with the mixture. In this study, these mixtures probably do not grow as fast as pure $N$. dombeyi plantations, since this species has a greater growth and site occupancy (Donoso et al. 1999, Lusk and Ortega 2003, Donoso et al. 2015) than the other Nothofagus, but they can definitely have a greater timber value considering that $N$. dombeyi is the least valuable species among these Nothofagus (Hall \& Witte 1999) and exhibits a greater tendency to forking that increases management costs (Donoso et al. 2015). In other words, mixtures could not only enhance biodiversity and other ecosystem functions and services, but also the economic value of the system. These mixtures would not only have stand-level advantages but would also enhance landscape biodiversity in southcentral Chile where plantation monocultures with Pinus 
radiata D.Don or with Eucalyptus species have created significant biodiversity problems (Heilmayr et al. 2020). This is not only an important result from an economic or ecological perspective, but also suggests the limitations of a traditional reductionist view of forestry, based on optimization through homogenisation. New evidences on the synergies associated to mixed-species plantations weaken the traditional industrial paradigm of natural resources in which trees are seen as objects, not subjects, and forestry is conceived in terms of competition among trees, not in cooperation among them. Finally, the fact that facilitation and/or complementarity did emerge as a synergy from the diversity of native species confirm the hypothesis that inspired the original plantation, and gives robustness to the ecosystems view of nature on science and natural resources management.

\section{Conclusions}

Mixed-species plantations with Nothofagus species have the potential to increase the productivity compared to pure plantations of some of these species, especially $N$. alpina. In addition to productivity, an important issue is that these mixed plantations can have a greater economic value, especially considering that $N$. dombeyi exhibits faster growth but a lower commercial timber value and greater silvicultural costs. Best species combinations seem to occur with species with contrasting silvical characteristics, which should be considered for further studies with these or other species.

\section{List of abbreviations}

Diameter at breast height (d)

Total height $(\mathrm{h})$

Volume (v)

Deciduous neighbourhood (DN)

Evergreen neighbourhood (EN)

Iterative Hegyi Index (ITH)

Akaike's Information criteria (AIC)

The root mean square differences (RMSD)

The aggregated differences (DA)

Absolute value differences (DAA)

Confidence intervals (CI)

Current annual increment (CAI)

Mean annual increment (MAI)

\section{Competing interests}

The authors declare that they have no competing interests.

\section{Authors' contributions}

PO conceived the study, participated in the design of the study, collected information in the field, and performed the statistical analysis. PD participated in its design of the study, and has been involved in drafting the manuscript and revising it critically, especially leading the Introduction, Discussion and Conclusion sections. AE established the plantation, participated in its design and coordination, and helped to draft the manuscript.

\section{Additional Files}

Additional File: Significant differences between neighbourhoods for cumulative growths and mean annual increment for three Nothofagus species.

\section{Acknowledgements}

Thanks to Christian Salas-Eljatib (Professor, Center for Modeling and Monitoring of Ecosystems of the Universidad Mayor, Santiago, Chile) for the positive and helpful comments in the statistical section. Thanks to "Denébola producción audiovisual" for advice and training in graphic design. Finally, we thank the anonymous reviewers of the manuscript who greatly contributed to improving the quality and message of the manuscript.

\section{References}

Brundu, G., \& Richardson, D. (2016). Planted forests and invasive alien trees in Europe: A code for managing existing and future plantings to mitigate the risk of negative impacts from invasions. NeoBiota, 30, 5-47. https://doi.org/10.3897/neobiota.30.7015

Capra, F. (1997). The Web of Life: a new synthesis of mind and matter. London, UK: Harper Collins.

CIREN (Centro de información de Recursos Naturales). (1990). Mapa digital de distritos agroclimáticos, $\mathrm{X}$ región, estudio "Inventario y contruccción carta base computacional”. [Publicación CIREN]. Santiago, Chile.

CIREN (Centro de información de Recursos Naturales). (2003). Agrological study of region-descriptions of soils, materials and symbols (Descripciones de suelos y materiales y símbolos - Estudio Agrológico de la X Región). [Publicación CIREN]. Santiago, Chile.

Cubbage, F., MacDonagh, P., Sawinski Júnior, J., Rubilar, R., Donoso, P.J., Ferreira, A., Hoeflich, V., Morales, V., Ferreira, G., Balmelli, G., Siry, J., Noemi Báez, M., \& Alvarez, J. (2007). Timber investment returns for selected plantations and native forests in South America and the Southern United States. New Forest, 33(3), 237-255. https://doi.org/10.1007/ s11056-006-9025-4

Diaz-vaz, J., Poblete, H., Juacida, R. \& Devlieger, F. (2002). Maderas Comerciales de Chile. Valdivia, Chile: Maria Cuneo Ediciones.

Donoso, C. (2013). Las especies arbóreas de los bosques templados de Chile y Argentina Autoecología. Valdivia, Chile: Marisa Cuneo Ediciones.

Donoso, P.J., Donoso, C., \& Sandoval, V. (1993a). Proposición de zonas de crecimiento de renovales de roble (Nothofagus obliqua) y raulí (Nothofagus alpina) en su rango de distribución natural. Bosque, 14(2), 37-55. https://doi.org/10.4206/ bosque.1993.v14n2-06 
Donoso, P.J., Monfil, T., Otero, L., \& Barrales, L. (1993b). Estudio de crecimiento en plantaciones y renovales manejados de especies nativas en el área andina de las Provincias de Cautín y Valdivia. Ciencia e Investigación Forestal, 7(2), 253-288.

Donoso, P., Cabezas, C., Lavanderos, A. \& Donoso C. (1999). Desarrollo de renovales de coihue común (Nothofagus dombeyi (mirb.) Oerst.) en la Cordillera de la Costa y de los Andes de la provincia de Valdivia en sus primeros 25 años. Bosque, 20(2) 9-23. $\quad$ https://doi.org/10.4206/bosque.1999. v20n2-02

Donoso, P.J., \& Otero, L.A. (2005). Hacia una definición de un país forestal: ¿Dónde se sitúa Chile? Bosque, 26(3), 5-18. https://doi.org/10.4067/S071792002005000300002

Donoso, P.J., \& Soto, D.P. (2010). Plantaciones con especies nativas en el centro-sur de Chile: experiencias, desafíos y oportunidades. Bosque, 47, 10-17.

Donoso, P.J., Muñoz, A., Thiers, O., Soto, D.P. \& Donoso, C. (2011). Effects of aspect and type of competition on the early performance of Nothofagus dombeyi and Nothofagus nervosa in a mixed plantation. Canadian Journal of Forest Research, 41, 10751081. https://doi.org/10.1139/x11-019

Donoso, P.J., Soto, D.P., Coopman, R.E., \& RodríguezBertos, S. (2013). Early performance of planted Nothofagus dombeyi and Nothofagus alpina in response to light availability and gap size in a highgraded forest in the south-central Andes of Chile. Bosque, 34(1) 23-32. https://doi.org/10.4067/ $\underline{\text { S0717-92002013000100004 }}$

Donoso, P.J., Navarro, C., Soto, D.S., Gerding, V., Thiers, O., Pinares, E., Escobar, B., \& Sanhueza, M.J. (2015). Manual de plantaciones de raulí (Nothofagus alpina) y coihue (Nothofagus dombeyi) en Chile. Temuco, Chile: Carla Duhalde.

Donoso, S. (2003). Potencialidad de plantaciones de Nothofagus obliqua en el sur de Chile. In: XII Congreso Forestal Mundial. Quebec. Canadá. 21-28 September 2003.

Echeverría, C., \& Lara, A. (2004). Growth patterns of secondary Nothofagus obliqua- $N$. alpina forests in southern Chile. Forest Ecology and Management, 195, 29-43. https://doi.org/10.1016/j. foreco.2004.02.034

Elíades, L.A., Cabello, M.N., Pancotto, V. Moretto, A., Ferreri, N. A., Saparrat, M. \& Barrera, M.D. (2019). Soil mycobiota under managed and unmanaged forests of Nothofagus pumilio in Tierra del Fuego, Argentina. New Zealand Journal of Forestry Science, 49: 7. https://doi.org/10.33494/nzjfs492019x53x

Esse, C., Donoso, P.J., Gerding, V., \& Montoya-Encina, F. (2013). Determination of homogeneous edaphoclimatic zones for the secondary forests of Nothofagus dombeyi in central-southern
Chile. Ciencia e investigación agraria, 40(2), 351-360. https://doi.org/10.4067/S071816202013000200010

FAO (Food and Agriculture Organization of the United Nations). (2016). $2^{\circ} \mathrm{ed}$. Global Forest Resources Assessment 2015. How are the world's forests changing? Online report. Accessed 20 February 2020. http://www.fao.org/3/a-i4808e.pdf

Grosse, H., \& Quiroz, I. (1999). Silvicultura de los bosques de segundo crecimiento de roble, raulí y coigüe en la región centro-sur de Chile. In Donoso, C., Lara, A.B., Basso, I., \& Otero, L. Viverización y platación de Raulí, Roble y Coigüe. Silvicultura de los bosques nativos de Chile (pp. 95-125). Santiago, Chile: Editorial Universitaria.

Hall, M., \& Witte, M. (1998). Maderas del sur de Chile. Santiago, Chile: Instituto de Educación Rural Ediciones.

Heilmayr, R., Echeverría, C., \& Lambin, E.F. (2020). Impacts of Chilean forest subsidies on forest cover, carbon and biodiversity. Nature Sustainability, 3, 701-709. https://doi.org/10.1038/s41893-020$\underline{0547-0}$

Kelty, M.J. (2006). The role of species mixtures in plantation forestry. Forest Ecology and Management, 233, 195-204. https://doi. org/10.1016/j.foreco.2006.05.011

Lee, W.K., von Gadow, K., Chung, D.J., Lee, J.L., \& Shin, M.Y. (2004). DBH growth model for Pinus densiflora and Quercus variabilis mixed forests in central Korea. Ecological Modelling, 176, 187-200. https://doi. org/10.1016/j.ecolmodel.2003.11.012

Lenderman, T., \& Stage, A. (2001). Effects of competitor spacing in individual-tree indices of competition. Canadian Journal of Forest Research, 31, 21432150. https://doi.org/10.1139/x01-153

Lu, H., Mohren, G., del Río, M., Schelhass, M., Bouwman, M., \& Sterck, F.J. (2018). Species mixing effects on forest productivity: A case study at stand-, speciesand tree-level in the Netherlands. Forests, 9(11): 713. https://doi.org/10.3390/f9110713

Lusk, C., \& Ortega, A. (2003). Vertical structure and basal area development in second-growth Nothofagus stands in Chile. Journal of Applied Ecology, 40, 639-645. 2664.2003.00827.x

Lyle, J.T. (1999). Design for human ecosystems. Landscape, land use, and natural resources. USA: Island Press.

Pinheiro, K., Bates, D., DebRoy, S., \& Sarkar, D. the R Core Team. (2017). Nlme: Linear and nonlinear mixed effects models, R. package version 3.131 p.

Piotto, D. (2008). A meta-analysis comparing tree growth in mocoultures and mixed plantations. Forest Ecology and Management, 255, 781-786. https:// 
doi.org/10.1016/i.foreco.2007.09.065

Pretzsch, H., Schütze, G., \& Uhl, E. (2012). Resistance of European tree species to drought stress in mixed versus pure forests: evidence of stress release by inter-specific facilitation. Plant Biology, 15, 483-495. https://doi.org/10.1111/j.1438$\underline{8677.2012 .00670 . x}$

Pretzsch, H., \& Forrester, D.I. (2017). Stand dynamics of mixed-species stands compared with monocultures. In: Pretzsch, H., Forrester, D.I., \& Bauhus J. (Eds.), Mixed-species forests (pp. 117209). Berlin, Germany: Springer. https://doi. org/10.1007/978-3-662-54553-9 4

R Core Team. (2017). R: A language and environment for statistical computing. R Foundation for Statistical Computing, Vienna, Austria. http:// www.R-project.org

Richards, F.J. (1959). A flexible growth function for empirical use. Journal of Experimental Botany, 10(29), 290-300. https://doi.org/10.1093/ $\mathrm{jxb} / 10.2 .290$

Salas, C. (2011). Modelling tree height growth of Nothofagus forests in South-Central Chile: Merging differential equations and mixed-effects models. PhD Thesis, Yale University, USA. 158 p.

Salas, C., Donoso, P.J., Vargas, R., Arriagada, C.A., Pedraza, R., \& Soto, D.P. (2016). The forest sector in Chile: An overview and current challenges. Journal of Forestry, 114(5), 562-571. https://doi. org/10.5849/jof.14-062

Schilleci, F., Todaro, V. \& Lotta, F. (2017). Connected lands: new perspectives on ecological networks planning. Switzerland: Springer Nature. 87 p. https://doi. org/10.1007/978-3-319-55233-0

Schnabel, F., Schwarz, J., Danescu, A., Fichtner, C., Nock, C.A., Bauhus, J., \& Potvin, C. (2019). Drivers of productivity and its temporal stability in a tropical tree diversity experiment. Global Change Biology, 25(12), 4257- 4272. https://doi.org/10.1111/ gcb.14792

Schulman, E. (1956). Dendroclimatic Change in Semiarid America. Tucson: University of Arizona Press.

Seifert, T., Seifert, S., Seydack, A., Durrheim, G., \& von Gadow, K. (2014). Competition effects in an afrotemperate forest. Forest Ecosystems, 1: 13. https://doi.org/10.1007/978-94-007-7448-3

Siebert, H. (2006). Silvicultura con apego a los Procesos Naturales y Plantaciones Mixtas. In Loewe V, González M. Plantaciones Mixtas. Un Modelo productivo con potencial para Chile (pp. 200-299). Santiago, Chile.

Stokes, M.A., \& Smiley, T.L. (1968). An introduction to Tree-Ring Dating. Chicago, IL, USA: University of Chicago Press.
Uteau, D., \& Donoso, P.J. (2009). Early individual growth of Eucryphia cordifolia and Laurelia sempervirens planted under different competition conditions in south-central Chile. Ciencia e Investigación Agraria, 361(1), 85-96. https://doi.org/10.4067/ $\underline{\mathrm{S} 0718-16202009000100008}$

Vandermeer, J. (1992). The ecology of intercropping. 237 p. New York, USA: Cambridge University Press. https://doi.org/10.1017/CB09780511623523

Vitali, V., Forrester, D.I., \& Bauhus, J. (2018). Know your neighbours: Drought response of Norway spruce, silver fir and Douglas fir in mixed forests depends on species identity and diversity of tree neighbourhoods. Ecosystems, 21, 1215-1229. https://doi.org/10.1007/s10021-017-0214-0

Wienstroer, M., Siebert, H., \& Müller-Using, B. (2003). Competencia entre tres especies de Nothofagus y Pseudotsuga menziessi en plantaciones mixtas jóvenes establecidas en la precordillera andina de Valdivia. Bosque, 24(3), 17-30. https://doi. org/10.4067/S0717-92002003000300002

Yang, L., Liu, N., Ren, H., \& Wand, J. (2009). Facilitation by two exotic Acacia: Acacia auriculiformis and Acacia mangium as nurse plants in South China. Forest Ecology and Management, 257, 1786-1793. https://doi.org/10.1016/j.foreco.2009.01.033 